\title{
The Effect of Property Tax to Public Expenditures in Rwanda
}

\author{
Ahishakiye Emmanuel Edison ${ }^{1}$ and Rusibana Claude ${ }^{2}$ \\ School of Business and Economics, Mount Kenya University \\ Kigali, Rwanda
}

\begin{abstract}
The government of Rwanda in 2013-2014 national budget has been affected by numerous factors includes, the reduction of donor's support disbursements plus the lagged impact that was delayedin 2012 adversely affected economic activities and public expenditures thus reducing domestic revenue collection in fiscal year of 2013-2014, from decentralized entities, therefore, from the RRA statistics report, indicated that annual decentralized tax collection within three fiscal year consecutive was perform below of $38 \%$ total revenue collected at the level of decentralized entities, that was affected the public expenditures of those entities, and also the report from Ngoma district indicated that, decentralized tax was performed below of $17 \%$ of annual district revenue collection within three years consecutive (2014/15, 2015/16, 2016/17). Is high Trading license tax rate discouraging taxpayers to pay tax, Is it high Rental income tax rate according to the ranges that was discourages taxpayers to pay tax? Moreover, is it high tax rate discourages taxpayers to pay tax) are all substantial statistical since their $\mathrm{P}$ value are less than 0.05 . it was clear that the variables were statistically significant with $F(6,91)=29.277$, $\mathrm{p}=0.000$ and it was clear that $63.6 \%$ of the all variances in what extent do taxes affect project success in Ngoma district can be explained by one's of the all variable in independent

Keywords:property tax,public expenditureand Rwanda
\end{abstract}

\section{Introduction}

All universally in substances of authority, tax devolution is the frenzy. Even separately from commonly discussed matters of subsidiarity and decentralization in the United states' rights, it has been to midpoint phase of rule investigates in two periods in a big figure of increasing and conversion markets (Bardhan, 2002).
In 2001, fiscal decentralization was sprung in Indonesia as a strategy reorganization to funding regional development, boost economic growth and alleviate poverty. In Vietnam, because of the devolution structure in 1998, 43\% of total national disbursements removed to the local governments. In Bolivian budget distributed in 1994 where $20 \%$ of tax income and $40 \%$ of spending accountabilities have been decentralized to local and metropolitan administrations (Faguet, 2004).

In Mexico executed regionalization reorganizations throughout $1995-1998$ in which $20.5 \%$ of tax revenue (beforehand together by the centralized regime) are now being disseminated between the countries under the bylaw of Countrywide Organization of Financial Synchronization. (Fausto \& Brenda, 2008).

Tax Decentralization Policy in Rwanda was accepted in 2001 like a mechanism to attain principles of good governance (via the improvement of transparency promotion, participation and accountability, sting up reactive decentralized system). Strengthening local economic development (via the execution of growth platforms effectively and effectiveness) and conveying worth and available services closed to the Rwandans. From the $1^{\text {st }}$ fiscal and decentralization policy were adopted, Rwanda has applied tax decentralization rules in straightforward way accepted in 2001 as instrument to accomplish good governance ideologies (through enhanced participation, advancement of transparency and culpability, and setting up responsive decentralized structure), enhance local economic development (through efficiency and effectiveness in execution of development programs) and bringing quality and accessible services closer to the citizens. Since the first Fiscal and Financial

Therefore, Ngoma district decentralized collection reports indicated that, in 2013-2014 tax collection amounted Rwf 230.5 million against to the whole target for district collection revenues of Rwf 630.0 million which was performed at 36.5 \%,. In 2014-2015 
decentralized tax, collection amounted Rwf 115.7 million against to the whole target for district collection revenues of Rwf 30.3 billion which was performed at $14.3 \%$. In 2015-2016 decentralized tax, collection amounted Rwf 141.8 million against to the whole target for district collection revenues of Rwf 1.2 billion which was performed at $11.8 \%$. In 2016-2017 decentralized tax collection amounted Rwf 153.6 million against to the whole target for district collection revenues of Rwf 939.7 million which was performed at $16.3 \%$.

\section{Data Collection Methods}

A descriptive survey design was employing Questionnaires and interviews were used to collect primary data. A descriptive research approach was carried out by use of participatory questionnaires with open ended as well as close questions.

The sample size was calculated through the use of Krejcie \& Morgan's (Creswell, 2009) formula of determining sample size

$$
n=\frac{N}{1+N *(e)^{2}}
$$

Where $\mathrm{n}=$ sample size; $\mathrm{N}=$ population size and $\mathrm{e}=$ Margin error which is equal to 0.05 for the case of research.

The sample size out of the target population of 6374 and all district staff were included in the project were as follows:

$\mathrm{N}=6374$

$$
\frac{6374}{1+6374(0.1)^{2}}=\frac{6374}{64.74}=98
$$

\section{Results}

\section{Table 1: Is there enough taxable property in Ngoma district?}

\begin{tabular}{llcccc}
\hline & Frequency & Percent & Validity percent & Cumulative Percent \\
\hline Valid & Not at all & 10 & 10.2 & 10.2 & 10.2 \\
& Less extent & 6 & 6.1 & 6.1 & 16.3 \\
& Some extent & 49 & 50 & 50 & 66.3 \\
& Great extent & 27 & 27.6 & 27.6 & 93.9 \\
& Very great extent & 6 & 6.1 & 6.1 & 100 \\
& Total & 98 & 100 & 100 & \\
\hline
\end{tabular}

Research data, 2020

Table1indicate how respondents think about taxable property, $6(6.1 \%)$ said property tax can be collected at very great extent, $27(27.6 \%)$ at great extent, 49 $(50.0 \%)$ at some extent. $83.7 \%$ of the respondents
, this means that the sample size is 98

$\mathrm{n}=$ Number of sample or Sample size.

$\mathrm{N}=$ Total population from which sample was made

$\mathrm{e}=$ Error tolerance or is the acceptance sampling error or margin of error

According to the above formula, determine by Yamane the recommended sample size of 98 respondents.

The research considered quantitative and qualitative method; it was conducted by collecting Primary data by using questionnaire approach and provided to target sampled respondents at district level, sectors and taxpayers. Therefore, the secondary data was collected from the different documentations, publications, District Report, RRA Report and Surveys, and other Reports provided by Rwanda national institutions.

\section{Data Collection Instruments}

From this, a researcher used primary and secondary information. Questionnaire was used to gather primary informationthat regarded to the matters relating the impacts of decentralized tax to the public expenditure in Rwanda, Ngoma district. According to Alan \& Emma (2007) Secondary data is the data by researchers who perhaps not have been complex in the gathering from the ground.

\section{Data Analysis Procedures}

Information was collected through questionnaire was organized and evaluated through expressive statistics thereby frequencies, percentage, tables using (SPSS) version 20 was used.

\section{Table 2: High tax rate discourages taxpayers to pay taxes}


ISSN 2455-6378

\begin{tabular}{llcccc}
\hline & Frequency & Percent & Valid Percent & Cumulative Percent \\
\hline Valid & Not at all & 4 & 4.1 & 4.1 & 4.1 \\
& Less extent & 12 & 12.2 & 12.2 & 16.3 \\
& Some extent & 32 & 32.7 & 32.7 & 49 \\
& Great extent & 17 & 17.3 & 17.3 & 66.3 \\
& Very great extent & 33 & 33.7 & 33.7 & 100 \\
& Total & 98 & 100 & 100 & \\
\hline
\end{tabular}

Research data, 2020

Table2indicates how respondents think about high tax rate and how it discourages taxpayers from paying taxes, $33(33.7 \%)$ said that high tax rates discourages taxpayers from paying taxes at very great extant, 17 $(17.3 \%)$ at greatt extents, $32(32.7 \%)$ at some extant.
$83.7 \%$ of the respondents agreed that high tax rates discourages taxpayers from paying taxes in Ngoma district and recommended that taxes if possible may be reduced to get may taxpayers.

\begin{tabular}{|c|c|c|c|c|c|c|}
\hline \multirow[t]{2}{*}{$\begin{array}{l}\text { Mod } \\
\text { el }\end{array}$} & & \multicolumn{2}{|c|}{$\begin{array}{l}\text { Unstandardized } \\
\text { Coefficient }\end{array}$} & \multirow{2}{*}{$\begin{array}{c}\text { Standardized } \\
\text { coefficient } \\
\text { Beta }\end{array}$} & \multirow[t]{2}{*}{$\mathrm{t}$} & \multirow[t]{2}{*}{ Sig. } \\
\hline & & $\mathrm{B}$ & Std. Error & & & \\
\hline \multirow[t]{7}{*}{1} & (Constant) & 1.928 & 0.366 & & 5.267 & 0 \\
\hline & Is it high tax rate discourages taxpayers to pay tax? & -0.443 & 0.077 & -0.576 & -5.747 & 0 \\
\hline & $\begin{array}{l}\text { Does a fixed asset tax declaration procedure affect } \\
\text { the increase of tax payment? }\end{array}$ & 0.602 & 0.067 & 0.853 & 8.956 & 0 \\
\hline & $\begin{array}{l}\text { Are tax penalties or fines discouraging taxpayers to } \\
\text { register their property in order to pay tax? }\end{array}$ & 0.014 & 0.07 & 0.016 & 0.205 & 0.838 \\
\hline & $\begin{array}{l}\text { Is it a challenge to calculate Value of taxable fixed } \\
\text { asset? }\end{array}$ & -0.123 & 0.051 & -0.177 & -2.424 & 0.017 \\
\hline & Is there enough taxable property in Ngoma district? & -0.065 & 0.093 & -0.071 & -0.705 & 0.483 \\
\hline & Do tax affect district work plan & 0.512 & 0.065 & 0.619 & 7.924 & 0 \\
\hline
\end{tabular}

a. Dependent Variable: To what extent do taxes affect project success of Ngoma district?

Table 3 revealed that holding independent variables constant (Is it high tax rate discourages taxpayers to pay tax, does a fixed asset tax declaration procedures affect the increase of tax payment Is it a challenge to

Table2: ANOVA

ANOVA $^{\text {b }}$

\begin{tabular}{lllllll}
\hline Model & & Sum of Squares & df & Mean Square & F & Sig. \\
\hline 1 & Regression & 17.650 & 4 & 4.412 & 10.978 & $.000^{\mathrm{a}}$ \\
& Residual & 37.381 & 93 & .402 & & \\
& Total & 55.031 & 97 & & & \\
\hline
\end{tabular}

calculate Value of taxable fixed asset and do tax affect district work plan) are all statistically significant since their Pvalue are less than 0.05 . 
a. Predictors: (Constant), do tax affect district work plan, are tax penalties or fines discourage taxpayers to register their property in order to pay a tax? , Is it a challenge to calculate Value of taxable fixed asset? Does fixed asset tax declaration procedures affect the increase of tax payment? Is it high tax rate discourages taxpayers to pay tax? Is there enough taxable property in Ngoma district?

b. Dependent Variable: To what extent do taxes affect project success of Ngoma district?

\section{Model Summary}

\begin{tabular}{lllll}
\hline Model & $\mathrm{R}$ & R Square & Adjusted R Square & Std. Error of the Estimate \\
\hline 1 & $.812^{\mathrm{a}}$ & .659 & .636 & .549 \\
\hline
\end{tabular}

a. Predictors: (constant), do tax affect district work plan, are tax penalties or fines discourage taxpayers to register their property in order to pay a tax? , Is it a challenge to calculate Value of taxable fixed asset? Does a fixed asset tax declaration procedure affect the increase of tax payment? Is it high tax rate discourages taxpayers to pay tax? Is there enough taxable property in Ngoma district?

Table 5 shows the anova test and model summary and from Table 5, it was clear that the variables were statistically significant with $\mathrm{F}(6,91)=29.277, \mathrm{p}=0.000$ and it was clear that $63.6 \%$ of the all variances in what extent do taxes affect project success in Ngoma district can be explained by one's of the all variable in independent

The study was an assessment for effect of decentralized tax to public expenditures in Rwanda. A study population of 6374 which was distributed as 17 District staff (Three District staffs, 14 sector accountant officers) 6,357 taxpayers from Ngoma district was used and 98 respondents were selected from that study population of which 28 (28.6\%) were female respondents and $70(71.4 \%)$ were male respondents. Education level was dominated by bachelor degree with $49(50 \%)$, followed by primary education level $24(24.5 \%)$ while diploma level were $14(14.3 \%)$, only $7(7.1 \%)$ of the respondents had secondary education level and $4(4.1 \%)$ of the respondents have informal education. The study revealed that $6(6.1 \%)$ said property tax can be collected at very great extent, $27(27.6 \%)$ at great extent, $49(50.0 \%)$ at some extent. $83.7 \%$ of the respondent agreed that taxable properties in Ngoma district are enough but the collection of taxes need to be revised and harmonized. It was clear that the variables were statistically significant with $\mathrm{F}(6,91)=$ $29.277, p=0.000$ and it was clear that $63.6 \%$ of the all variances in what extent do taxes affect project success in Ngoma district can be explained by one's of the all variable in independent

\section{Conclusion}

The findings presented in this research emphasizes and revealed that decentralized tax to public expenditures particularly tax propertytax,83.7\% oftheir respondents agreed that taxable properties in Ngoma district are enough but the collection of taxes need to be revised and harmonized. $83.7 \%$ of the respondents agreed that high tax rates discourages taxpayers from paying taxes in Ngoma district and recommended that taxes if possible may be reduced to get may taxpayers. $90.8 \%$ of the respondents agreed that taxes affect the work plan of Ngoma district

\section{Acknowledgement}

I wish to acknowledge Dr. RUSIBANA Claudefor his contribution to this work from the beginning up to it's the completion. I also wish to extend my acknowledgement to the Mount Kenya University, Ngoma District management for their support and collaborative in terms of data collection.

\section{References}

[1] Agnese Sacchi \& Simone Salotti (2012), "The effects of Fiscal decentralization on household income inequality" Spatial Economic Analysis Vol. 9, No. 2, p202-222

[2] Akpan, E. O. (2011). "Fiscal Decentralization and Social Outcomes in Nigeria" European Journal of Business and Management, Vol 3.

[3] Ariwodola, J. A. (2000) "Personal Taxation in Nigeria"(4th edition) Lagos: JAA Nigeria Ltd. Azfar, O. \& Jeffrey, L (2002). Federalist disciplines or local capture an empirical analysis of decentralization in Uganda.

[4] Arze del Granado F.J., Martinez-vázquez J. and Mcnab R. (2005) "Fiscal decentralization and the functional composition of public expenditures" Working paper 05-01, Andrew 
Young School of Policy Studies, Georgia State University;

[5] Bardhan, P. (2002) "Tax Decentralization of Governance and Development." Journal of Economic Perspectives, Vol.16 (4) PP 185205.

[6] Bhatia, H. L. (2009). "International economics" New Delhi: Vicas Pubs.

[7] Braithwaite, V. (2003) "Taxing Democracy" Understanding Tax Avoidance and Evasion. London: Ashgate.

[8] Bryn Welham, Edward Hedge (2015) "Investigated the Linkages between Decentralized tax and Public expenditures in developing countries"

[9] Chandran, E. (2004) "Research methods: a quantitative approach with illustrations fromChristian ministries". Nairobi: Daystar University

[10]Chang \& Lai (2004) "Collaborative Tax Evasion and Social Norms" Oxford economic journal, pp.344-368.

[11] Chinyere, C. J. (2000) "The Use of Consultants in Tax collection Analysis of the Accelerated Revenue Generation Program in River State" Nsukka: River states press.

[12] Fuest, C. and Ridel, N. (2009) 'Tax evasion, tax avoidance and tax expenditures in
ISSN 2455-6378

developing countries" A review of the literature'. Report prepared for the Department for International Development

[13] Gonzalez Alegre J. (2010) "Decentralization and the Composition of Public Expenditure in Spain" Regional Studies 44, 1067-1083; 1415 Ottobre 2011

[14] Gyurko, Joseph and Todd Sinai (2004) "The (un)changing Geographic distribution of housing tax benefits in 1988-2000" Tax policy and the economy, 18: 175-208.

[15]RRA Annual report 2014-2015 and 20152016

[16]RRA Tax statistics in Rwanda fiscal year 2015/2016, first Edition

[17] Umeora, C. E. (2013) "The effect of Value Added Tax on the Economic Growth of Nigeria"Journal of Economics and Sustainable Development, 4, No.6

[18] Wallace E. Oates (1969) "The Effects of Property Taxes and Local Public Spending on Property Values" An Empirical Study of Tax Capitalization and the Tiebout Hypothesis The Journal of Political Economy, Vol. 77, No. 6.pp. 957-971 